\title{
"NATIONES QUE SE TARTAROS APPELLANT": AN EXPLORATION OF THE HISTORICAL PROBLEM OF THE USAGE OF THE ETHNONYMS TATAR AND MONGOL IN MEDIEVAL SOURCES
}

\author{
Stephen Pow \\ Central European University \\ Budapest, Hungary \\ Powstephen@phd.ceu.edu
}

\begin{abstract}
Objective: An attempt is made to explain why Mongols were so often referred to as Tatars in thirteenth-century primary sources and to offer a new interpretation of how the usage of both ethnonyms evolved over the course of the Mongol Empire's expansion and dissolution.

Research materials: Primary sources were used which originated from Russian, Mongolian, Latin, Persian, Arabic, Chinese, and Korean authors. The Russian Novgorod and Galicia-Volhynia Chronicles, Secret History of the Mongols, Rashid al-Din, the Yuan Shi, and the Mengda Beilu were the most significant in formulating an argument. Secondary literature by leading figures in the field of Mongol history was consulted.

Research results and novelty: The main finding is that the different explanations found in primary source texts composed under Mongol governments for how these names were used in the pre-imperial period and for the double-naming phenomenon seem implausible when compared to the broader body of primary sources whose authors were not directed by an evolving Mongol imperial ideology. Furthermore, the various explanations cannot be combined into some workable model for how the double-naming phenomenon happened in the thirteenth century, since they contradict one another on fundamental issues such as whether Tatars still existed or were an extinct nation. As such, it is more plausible that the Mongols used the name "Tatar" to self-identify in the first three or four decades of the Mongol Empire's expansion. The gradual replacement of "Tatar" by "Mongol" was solidified by the development of imperial historiography in the 1250s and 1260s. This proposed scenario can make sense of the strange dichotomy in the primary sources regarding ethnonyms. Novelty is found in the comparison of Chinese and European sources and the attempt to synthesize their claims - an approach which highlights potential avenues of research for experts in Islamic, Russian, and Chinese sources.
\end{abstract}

Keywords: Tatars, Mongols, Tartars, Mongol Empire, Golden Horde, Russian Chronicles, Ethnonyms, Early Mongol Empire, Ethnogenesis, Chinggis Khan

For citation: Pow S. "Nationes que se Tartaros appellant": An Exploration of the Historical Problem of the Usage of the Ethnonyms Tatar and Mongol in Medieval Sources. Zolotoordynskoe Obozrenie=Golden Horde Review. 2019, vol. 7, no. 3, pp. 545-567. DOI: 10.22378/2313-6197.2019-7-3.545-567

Why is "Tatar" - "Tartar" in Western European sources - rather than "Mongol" the ethnonym by which the conquerors are usually labelled in source materials written by outsiders during Chinggis Khan's conquests and afterwards? This problem is more complex than it first appears, troubling scholars who have looked in 
depth at the sources regarding the Mongol Empire, Golden Horde, and other successor states. After all, the authors of our sources came from diverse, geographically diffuse societies and wrote in many distinct languages. Furthermore, the Tatar tribe was, according to some of those sources, a hated enemy of Chinggis Khan and the Mongols. How could so many groups of people through Europe, the Islamic world, Inner Asia, and East Asia, having very limited interaction with each other, but some interaction with the conquering Mongols in the thirteenth century, all make the mistake of not just calling the Mongols by the wrong name, but even the name of their foes?

A simple explanation has been traditionally offered for how such a curious phenomenon could have come about - namely, a case of mistaken identity. However, several leading scholars of the Mongol Empire have suggested that it remains a lasting mystery. István Vásáry has stated, "The Tatar tribes were Chingis Khan's ancestral enemies, and the reason why the victorious Mongol conquerors of Chingis Khan were later called Tatars by most of the sources is a historical puzzle unsatisfactorily explained to this day" [55, p. 9]. This issue gets even stranger when we note that Chinggis Khan's Mongols are recorded in their own official, standard narrative to have annihilated the Tatars as a people following their final victory over them in 1202. David Morgan observes that if the Tatars "ceased to exist as an identifiable tribe" before Chinggis Khan's period of expansion beyond the Mongolian plateau even began with his unification of its peoples in 1206, then it has never been satisfactorily explained why Tatar "should have become so widely the name by which the conquerors as a whole were known" [38, p. 57]. Peter Jackson repeats the heretofore conventional explanation for this curious phenomenon with a hint of reservation, noting that the Tatar tribe, once dwelling in today's Manchuria and the very eastern fringes of Mongolia, "may have played" a prominent political role in the eighth and ninth centuries and "it seems" their name became synonymous with non-Turkish steppe peoples in general at some undefined time. The Mongols, emerging from the eastern steppe, thus became synonymous with Tatars [30, p. 36].

The familiar refrain to anyone with the slightest curiosity about this issue is that persisting ethnonymic confusion surrounding Tatar and Mongol merely reflects a medieval misunderstanding. The Mongols of the thirteenth century apparently were misidentified by ignorant outsiders as the Tatars, even though during Chinggis Khan's rise, the Tatars were not simply another tribe in Mongolia but rather the Mongols' most detested enemies according to several sources. Misidentifications happen in the works of medieval writers, but the almost global scale of this alleged misidentification is among the most serious problems with accepting such an explanation. The range of sources and complexity of the issue make it difficult to discuss succinctly. It is also difficult to describe the problem or to structure a paper that approaches it systematically, let alone to explain how this situation could have happened.

For simplicity and the purposes of my argument, one can focus on it as a source problem, dividing texts into official sources and unofficial sources. By the former, four works that were the products of Mongol court historiography are meant; namely the Secret History of the Mongols, Rashid al-Din's Compendium of Chronicles, the Yuan Shi, and the Shengwu qinzheng lu. The concept of the official sources here is closely related to what Christopher Atwood referred to as the 
"standard narrative" in a recent work on Jochi's role in conquests in the western regions. Like Atwood's grouping, all four of these sources can differ in style and on details, but "they share a number of emphases and partisan assertions" that indicate they are all "historiography of the 1251 Toluid revolution. Together, these works in Mongolian, Chinese, and Persian languages set the basic lines of Mongolian Imperial Historiography in the Toluid realms of Yuan China and the Ilkhanate" $[5$, p. 36]. Besides conforming to a specific agenda, their material is closely intertwined - they are products of a dynastic agenda and they are the sources from which the story of Chinggis Khan's rise and defeat of the Tatars is largely derived.

On the other hand, there are what we will view as unofficial sources which here only means that these texts were written outside of Mongol courts. They come from a wide variety of genres and cultural contexts. They are not necessarily unofficial in character - some are the letters and decrees of popes and monarchs, or the reports of official ambassadors. By unofficial sources I intend simply to convey the sense that they contain statements and narratives that were not controlled and formed by Mongol Toluid courts. When we compare them, official sources all present a consistent message about what Mongol and Tatar respectively meant but it is often contradicted by the unofficial sources. Especially regarding ethnonyms, we would expect to see unofficial sources corroborate the narrative in the official sources better, were it totally historically accurate. Instead we see the opposite.

My argument is that these two sets of sources cannot be reconciled in a way that creates a cogent picture; sources disagree on whether Chinggis Khan's people called themselves Tatars, how the mislabeling happened, whether Tatars were existent or extinct at the time of writing, whether they were the Mongols' enemies or allies, and whether they took part in the conquests. Faced with hints of confused memories, retrospective labelling, and perhaps politically motivated historical revisionism in the sources' handling of this issue, I contend that the Mongols likely employed "Tatar" as a broad endonym for a time, perhaps for the first three or four decades of the thirteenth century, before transitioning to Mongol as a preferred broad endonym. Tatar was out of favor by the mid-1240s, judging by the unambiguous reports of Mendicant emissaries on this point. Why this happened can only be inferred.

To support this point, I will first demonstrate that the traditional explanation relies on downplaying the scope of the usage of Tatar; often authors focusing on only one social region, usually Europe, have made this mistake. Secondly, I look at the official sources to show why they might not be our most reliable sources, at least on this specific issue. Thirdly, I will highlight certain statements and elements of the unofficial sources that make it impossible to reconcile them with the official account. I suggest that we instead seek an explanation that is in accord with the widest set of sources. Finally, I will offer some ideas for what the drivers might have been behind the Tatar ethnonym's displacement in favor of Mongol, which appears to have initially been a name used to designate Chinggis Khan's dynastic state.

\section{The Scope of the Problem: Europe's Tartars, Asia's Tatars}

The Franciscan friar, John of Plano Carpini, journeyed to the Mongols as a papal envoy (1245-1247) and his resulting report began with the words "Incipit Ystoria Mongalorum quos nos Tartaros appellamus" - "Here begins the History of 
the Mongols whom we call Tartars" [48, p. 11]. More than once, Carpini used this awkward designation for a people, only recently unknown to Latin Christendom, who were conquering much of the world and had recently campaigned up to the borders of Austria. He noted of his itinerary at another point, "Next we entered the land of the Mongols whom we call Tartars" [18, p. 60]. Statements of this kind inevitably raise the same nagging issues for historians that were already mentioned. If these people were called Mongols, why are "we" calling them Tatars in the first place? That is, if Carpini was aware after meeting the people in question that they were Mongols rather than Tatars ${ }^{1}$, why did he nevertheless generally persist with the error throughout his report? Moreover, who is encapsulated in Carpini's "we" the group making this error? Presumably, he intended it to mean Latin Christians, i.e. Europeans. The Dominican emissary Simon of Saint-Quentin who stayed with the Mongol army under Baiju in 1247 likewise noted: "speaking of themselves, the same Tartars call themselves Mongli or Mongol - a word which perhaps re-echoes Mosoth" [45, p. 92]. This etymology was related to an effort by the Dominicans to tie the Mongols to Biblical genealogies and prophecy.

The observations of Mendicant emissaries have been used to construct a narrative, still repeated up to the present, that it was strictly Western Europeans who referred to Mongols as Tartars/Tatars, persisting in it even when they knew better. Popular histories emphasize medieval European writers' tendency to tie the term Tartar to Tartarus, the lowest level of hell in classical mythology. Jack Weatherford links the "incorrect" usage of Tartar to the English chronicler Matthew Paris (d. 1259) and his description of the nomads appearing "like demons loosed from Tartarus" [58, p. 148]. In fact, Matthew Paris stated, as Carpini had, that the Tartar name originated from a river in their homeland [24, v.1, p. 314], and he quoted a Russian bishop in 1244 who claimed the name originated from a chieftain named Tartar [24, v.2, p. 28]. Still Matthew Paris used the opportunity to make the Tar$\operatorname{tar} /$ Tartarus puns that appeared in European writings of the mid-thirteenth century with obnoxious frequency. For example, the churchman Rogerius, taken captive by the Mongols in Hungary in 1241, wrote of the experience, "He who should fall into the hands of the Tartars [...] will feel that he is the prisoner not of the Tartars but of Tartarus" $[10, \text { p. 134-135] }]^{2}$. James Chambers posited that the misidentification stemmed from the visits of Friar Julian, a Hungarian Dominican, to Magna Hungaria in the $1230 \mathrm{~s}$, conjecturing that Julian took the Russian term for the newcomers on their frontiers, "Tatar," and altered it in his writing to "Tartari" - thus implying they were people from hell [15, p. 64].

Such explanations have appealing simplicity, but their oversimplification of the issue makes them untenable. Recently, Roman Hautala has admirably pointed

\footnotetext{
${ }^{1}$ According to Salimbene de Adam, Carpini informed him in person that the name of these people was more properly pronounced as "Tatar," rather than the conventional "Tartar." Moreover, after noting that, Salimbene opted to use Tatar in his own chronicle. To be clear, Carpini was referring in this case to the Mongols ruling over Asia rather than an extinct regional tribe that formerly rivaled Chinggis Khan.

${ }^{2}$ A statement attributed to Louis IX that "if these people, whom we call Tartars, should come upon us, either we will thrust them back into the regions of Tartarus, whence they emanated, or else they shall send us to heaven" [24, v. 1, p. 314], suggests that European leaders and commentators alike were making use of the close resemblance of Tartar to Tartarus for propagandistic purposes or to reflect their eschatological preoccupations.
} 
out the complexity of the transmission of information about the Mongol conquests in the early thirteenth century; it cannot be reduced to a single stream of information originating from a single text by Matthew Paris or Friar Julian. There were reports reaching Europe from crusaders in the Holy Land of the coming invincible army of "King David" in 1221. These actually described Chinggis Khan's campaign against the Khwarazmians, which began only in 1219, with some degree of accuracy. In fact, the little-known Quilichino of Spolato's History of the Battles of Alexander the Great written in 1236 contains the innovation of directly associating the "Tartar crowd" with the ancient concept of Tartarus. Moreover, the earliest recorded mentions in Latin of "Tartari" are found in letters written to the pope by the Georgian Queen Rusudan and Amirsrpasalari Ivane, one of her leading nobles, in 1223. Shortly afterwards, Henry of Livonia, living in distant Riga, reported in his chronicle on the defeat of the Russians at the Battle of the Kalka which occurred in 1223 [26, p. 314-315, 320-322; 14, p. 205]. He provided an accurate, clearly informed version of events and named the nation that had won the battle: "Tartars." In the same context of the Baltic, we might think of the famous passage in Matthew Paris about how the English herring trade was disrupted because merchants in the Baltic region were not coming to Yarmouth to purchase owing to their fear of "Tartar" attacks and so the price of herring plummeted in England [24, v.1, p. 131]. One might imagine that English merchants, watching their financial ruin unfolding in 1238, were eager to know something about the people who had disrupted the herring fishery - including their ethnonym. The answer was probably "Tatar" or "Tartar," seeing as Matthew Paris recorded it. Even if historians must rely on texts to construct the movement of this ethnonym, this commercial episode offers us a hint that it was not only churchmen and magnates who transmitted the word "Tartar" to Europe, but their writings have survived.

Only if Europeans exclusively had mistakenly called the Mongols by some variation of Tatar or Tartar would the traditional explanation make sense, and clearly Europeans did not initially prefer the word "Tartar" because it lent itself to pejorative puns. They first recorded it because it was the word that they had received from informants on the fringes of the Latin West. Judging by a letter on the journey of Friar Julian to Magna Hungaria in 1234-35, the Alans, Russians, and Volga Hungarians already labeled the newcomers to their region as "Tartars" [21, p. 129-133; 50, p. 538-541]. Georgians called them Tatars [31, p. 319]. So, if we accept the glib explanation offered by modern writers of how "Tartar" caught on in Europe $^{3}$, we are still faced with the problem of why Russians and other peoples were already using the misnomer that spread to Europe. The usage of Tatar was even more widespread than Europe, Russia, and the Islamic sphere, appearing also in the earliest Chinese reports documenting the Mongol Empire's rise.

Almost immediately after Chinggis Khan went to war with the Jin Dynasty, a Song emissary to the Jin in 1212 described the invaders as "Tatars" [22, p. 179]. This terminology was likewise used in the earliest record of a Song Dynasty envoy who visited the Mongols. The Mengda Beilu, written by Zhao Hong in 1221, stated that in the land of Chinggis Khan there were three groups - the Black Tatars, White Tatars, and Wild Tatars. Chinggis Khan and his leading officials were all Black

\footnotetext{
${ }^{3}$ It can be acknowledged that the similarity of Tartar to Tartarus might explain why Europeans generally persisted with the /r/ sound in the word, even if they knew that Tatar was accurate as Carpini told Salimbene de Adam.
} 
Tatars [39, p. 3]. Regarding the term Mongol, Zhao Hong noted that there had been in the same region in the first half of the twelfth century a "Mongol State" (蒙古斯國) but he carefully interrogated the present Tatars regarding it and found that they, being in a primitive condition, knew nothing about it. However, out of admiration for it, having been influenced by refugee scholar-officials from the Jin Empire who had come into Chinggis Khan's service, they were now calling theirs the "Great Mongol State" (大蒙古國) [39, p. 16]. This account stands in stark contrast to that found in the later official sources composed in Mongol-ruled courts, which will be discussed below. Zhao Hong's very early account held that Chinggis Khan and his fellow Tatars were inspired by a story told to them by Chinese or Jurchen literati about an ephemeral, half-forgotten steppe federation called Mongol and decided to call their own incipient state after it. Regarding Muqali, Chinggis Khan's second-in-command overseeing the war against the Jin, the envoy stated that he always spoke of himself as "we Tatar" and that all of the high officials of the state had no idea what Mongol (蒙) actually meant [39, p. 17]. Perhaps Zhao Hong meant they used the label without knowing its recorded history. We would expect Muqali to call himself an ethnic Mongol rather than a Tatar, if Tatars were mortal enemies of Chinggis Khan - but the word Mongol seems to have had at this point a strictly dynastic-state connotation.

Another Chinese source, the Heida Shilue, consists of the brief reports of two Song emissaries who visited Ögedei's court in Mongolia in 1233 and 1235-1236 respectively. The earlier emissary, who conducted his mission just as the Jin were falling, indicated the conquerors were "Black Tatars" and their polity was still called "Great Mongol." He suggested that "Mongol" stemmed from an otherwise undocumented "Mongol Mountain," or that it was related to the Mongolian word for silver. Since the defeated Jurchens had called their dynasty "Da Jin" (Great Gold), their Tatar conquerors were calling their state "Great Silver." The emissary was providing an explanation that he presumably heard from his hosts about the origin of the dynastic-state label, "Mongol" [39, p. 112].

It is hard to ignore the testimony in early, dispassionate reports of ambassadors about the respective usages of Tatar and Mongol in the 1220s and 1230s and it does not conform to anything found in the official sources. The fact is that in almost every relevant source, we are likely to find Tartar/Tatar rather than, or in addition to, Mongol. Addressing the widespread use of the Tatar ethnonym, Rashid al-Din (d. 1318) provided an ample list of nations that had the persistent habit of using Tatar: "All Turkic peoples are still called 'Tatar' in the realms of Cathay, Hindustan, Chin and Machin, the lands of the Qirgiz, Kilar-Bashghurd, the Qipchaq Steppe, the territories of the north, the Arab peoples, Syria, Egypt, and North Africa" [53, p. 38]. According to the Persian court historian, sedentary and nomadic peoples of almost every major region across Eurasia and North Africa still used Tatar in the early 1300s.

It is jarring that Rashid al-Din's ethnographic description of the Tatars, apparently a former tribe in eastern Mongolia wiped out in 1202 by Chinggis Khan, includes an explanation of how their ethnonym came to be used across much of the world for all Turkic peoples. How could such a thing have happened? Rashid alDin suggested it was the prestige of the Tatar name in an undefined former era that accounted for it. But in fact, the Persian historian's list of regions whose people 
used the ethnonym Tatar was far from comprehensive. We find references to "Tartararíki" in an Icelandic geographical treatise from the mid-thirteenth century, and a saga records the Norwegian king, Haakon IV, resettling refugees from Bjarmaland who fled the "Tattarar" [54, p. 223-224, 236 $]^{4}$. Outside of works composed under Mongol auspices, some variation of "Tatar" often shows up in Chinese sources composed during Chinggis Khan's time and even after the fall of the Yuan Dynasty. It shows up in the Koryo Dynasty of Korea's official history, for instance when Ögedei Khan identifies himself and his people as “we Tatars" (達達) in the transcript of a letter to the king of Korea dated to 1231. Bolstering the claims of the Song envoys, the khan seems to confirm that Mongol was a political term in a follow-up letter dated to 1232 in which he refers to himself as emperor of the Mongol Great Royal Court (or Dynasty) and State (蒙古大朝國) [33, p. 228-229, 235]. "Tatar" is the ethnonym also used to label the Mongols in Javanese sources describing the Yuan invasion of Java in 1293 [9, p. 53].

Those researchers who focus on certain sets of texts (Latin, Arabic, Chinese, etc.) can imagine that only the authors in one societal milieu were mistakenly calling Mongols by Tatar, or at least it is often presented that way. But when we realize the scope of the "misidentification," it is difficult to accept that explanation. Though many researchers accept the account found in the official sources that Tatar and Mongol were the ethnonyms of two distinct and opposed enemy tribes in the pre-unification period, there are problems with that as we will explore in the next section.

\section{The Problem of the Standard Narrative in the "Official Sources"}

There are four official sources composed in Mongol courts that, within the context of recording the details of Chinggis Khan's life, provide substantial material about the early origins of the Mongol Empire and the ethno-political groupings on the steppes at the Mongol Empire's formation. They all contain essentially the same narrative that Chinggis Khan was an ethnic Mongol who annihilated the rival Tatar people in the course of his struggle for supremacy.

Chief among the official sources is the Secret History of the Mongols, composed in Mongolian as a historical chronicle and undoubtedly the fullest record of how the Mongols viewed themselves and their founder [7, p. 1]. The dating is a long topic of scholarly debate. A coda indicates that it was written in the "mouse year" at a great assembly and Atwood suggests that he has found some evidence for such an assembly in 1252 [7, p. 12-14]. Even so, there are problems with the text, such as an event that actually took place in 1258 being inserted anachronistically into the reign of Ögedei, which suggests it could have theoretically been written in the next mouse year, 1264. Atwood suggests there were some small changes made during the reign of Khubilai [7, p. 39-44]. If the main text dates to 1252, it was composed in a context that saw the Mongol Empire again entering a period of stability initiated by the enthronement of the fourth khan, Möngke. This followed

\footnotetext{
${ }^{4}$ As a general name for the conquerors from Mongolia, Tatar is regularly found in Russian, Armenian, Georgian, Arabic, Byzantine Greek, and often Persian sources, including those written in India.
} 
roughly a decade of strife and political infighting when Chinggisid princes' factions vied for power and legitimization.

Next among these "four fundamental chronicles on the origins of the Mongol Empire" is the Shengwu qinzheng $l u$ (聖武親征錄), a Chinese abridged translation of a Mongolian original that, in Christopher Atwood's assessment, could only have been composed sometime after 1263 in the flurry of historiographical activity fostered at Khubilai Khan's court. Its material draws heavily from the Secret History [4, p. 1]. We have, too, the Compendium of Chronicles which was compiled by Rashid al-Din, an important official of the Ilkhanate, around 1304. Textual analysis shows that Rashid al-Din's annals of Chinggis Khan were clearly based on the lost original source also used for the Shengwu qinzheng lu. Thus, about $90 \%$ of the Chinese text matches the later Persian text. They are almost identical [4, p. 2].

Lastly, there is the Yuan Shi which was the official history of the Mongol Yuan Dynasty compiled under Ming auspices shortly after the last Mongol emperor was driven from power in 1368. The first chapter of the Yuan Shi, Chinggis Khan's annals, is the same material found in the Shengwu qinzheng lu and Rashid al-Din's annals of the reign of Chinggis Khan, albeit with slight changes in date and abridgement [4, p. 7-8]. Scholars such as Atwood have elucidated that these sources, which might have once been mistaken for separate traditions because of the different languages of composition, originated from the same Veritable Records material. These three documents are particularly synoptic in quality, whereas the Secret History deviates more from the others. Still, three fifths of the Secret Histo$r y$ 's text matches with the material on Chinggis Khan found in the other three texts, and the account in the Shengwu qinzheng $l u$ of the reign of Ögedei is identical to material in the later Yuan Shi $[4$, p. 8].

In the Secret History's version of events - mirrored by the accounts found in Rashid al-Din's annals section which is often called the Tale of Chinggis Khan, the Yuan Shi's first chapter, and the majority of the Shengwu qinzheng lu - the Tatars were the hereditary enemies of Temujin, a Mongol, who became Chinggis Khan. Indeed, they played an important role in shaping his destiny. In the first chapter, Chinggis Khan's father named his eldest son Temujin after a Tatar chieftain he had defeated before being poisoned treacherously by the Tatars $[19, \mathrm{p} .16]$. This initiated a period of great suffering and poverty for Chinggis Khan, his siblings, and mother after they were abandoned by their followers. Eventually becoming a powerful leader, Chinggis Khan fought a climactic battle with the Tatars, stating beforehand, "From old days, the Tatar people have been our mortal enemies, the people who have destroyed our fathers and forefathers" [19, p. 56]. Having defeated and captured them, the Tatars were systematically eradicated. Chinggis Khan ordered his followers to "kill them to the last" man and enslave the few survivors [19, p. 76-79]. In the official record, the conqueror's hereditary enemies were destroyed as a people in 1202 .

Since these official sources all emerged from the same closely controlled imperial historiographical project, their agreement on the past usage of the Mongol and Tatar ethnonyms is not as persuasive as materials written at the actual time of events they describe. There was a strong agenda controlling what was allowed to be in the official historical record, Khubilai Khan himself playing a role in the creation of the standard narrative. The Yuan Shi reports that when he saw the an- 
nals of the reign of his deceased brother, Möngke Khan, he angrily demanded that the court historians revise it [2, p. 120].

There are other problems with the official sources. Tribes in the pre-unification steppe seem to have had a protean quality which is at odds with the rigid ethnic divisions found in the standard narrative. For instance, we might wonder why the official sources disagree about the tribal affiliations and backgrounds of even the most important figures in the Mongol Empire's founding, like Chinggis Khan's lifelong retainer, Boroqul [53, p. 85]. Christopher Atwood notes a feature in scholarship he calls "Secret History fundamentalism" - a tendency when faced with such discrepancies to assume the Secret History is correct and any divergence from it reflects an error. However, the variations in pre-Chinggisid genealogies are too complex to be solved in such a manner, and at least six divergent genealogies circulated with medieval authors trying unsuccessfully to resolve their contradictions. We see for instance the Yuan Shi explaining how Bodonchar, the great ancestor of Chinggis Khan, had an illegitimate son "Tatar" who begat the Tatar people, but in the Secret History that same genealogy is applied to the origins of the Jadaran family of Jamuqa [6, p. 6-7, 9-10]. Evidently, the genealogies could be altered to establish the origins of villains. Furthermore, it is not entirely clear how Mongol is being used as a term, Jamuqa calling the Kereyit ruler, Ong Khan, a "Mongol" at one point in the Secret History $[19$, p. 39]. If Chinggis Khan is being packaged as a hereditary ruler of the "Mongol" tribe, then what should we make of his subservience to Ong Khan - should we not consider him a Kereyit? Might that tribal name's connection to qara (black) explain why Chinggis Khan and his people are "Black Tatars" in the early Song Chinese reports? Regarding Chinggis Khan's rise, whom he destroyed and whom he spared seems to have been based more on loyalty and submission to him than on any bonds of tribal identity. Chinggis Khan evidently had a liberal idea of what a Mongol was, something that again stands at odds with the picture encountered in the standard narrative of his rise.

With regard to the Secret History's insistence that Chinggis Khan and his people were Mongols and Atwood's proposed dating of the work to 1252, this was the point in time when William of Rubruck, acting as an unofficial emissary of Louis IX, journeyed to Möngke's court, shortly after the "Toluid revolution" snatched supreme power from the Ögedeids. The friar observed in those he met a desire to be called Mongols, and an aversion to being called Tartars. Rubruck wrote that the Mongols were the tribe to which Chinggis Khan belonged, and that the Mongols and "other poor people" [18, p. 122] called Tartars appointed Chinggis Khan as their leader and united to overthrow Ong Khan of the more powerful Kereyit people. They emerged victorious and this marked the beginning of their empire. Rubruck explained that Chinggis Khan then sent the Tartar people, specifically, in all directions to conquer so that it was their label, rather than the more proper designation of Mongol, by which the invaders had become known as they advanced across the continent. However, Rubruck heard that by the time of his own travels through the Mongol Empire in the early 1250s, the Tartars had been almost eradicated through continual warfare, so that "the Mongols wish to abolish their [Tatar] name and bring their own [Mongol] to the fore" [18, p. 123]. Rubruck mentioned, even Sartaq on the Volga wished to be called a Mongol.

Such was the social milieu in which the standard narrative was created. But if the official narrative's account of how the ethnonyms Tatar and Mongol were used 
in the pre-unification Mongolian steppe were accurate, then William of Rubruck's explanation makes no sense. If the Principle of Parsimony is reliable in this case, then we ought to suspect the problem exists in the official sources rather than trying to make the statements found in the much vaster and diffuse body of "unofficial sources" conform to them.

As mentioned earlier, Rashid al-Din also tried to justify the confusion by referring to an undefined past period when "because of the strength and glory of the Tatars" [53, p. 38], other tribes were inclined to assume their name and identity which resulted in the name still being applied across Eurasia to the later Mongol conquerors:

"Indeed they considered it an honor to call themselves Tatar, just as at present, because of the great fortune of Genghis Khan and his urugh, because they are Mongols, other tribes of Turks like the Jalayir, Tatar [sic], Oyirat, Öng'üt, Kereyit, Naiman, Tangqut, etc. each of which has its own special name and sobriquet, all are proud to call themselves Mongol. Whereas before they used to deride this name, now their sons imagine that they have been known as Mongols from long ago, although it is not so. In ancient times, the Mongols were but one of all the tribes of nomadic Turks, but divine favor shone upon them, meaning that Genghis Khan and his urugh were to be of the Mongol race and many branches of them would come into existence" [53, p. 38].

Rashid al-Din's ethnographic discussion of the Tatar nation is extremely confused, often wavering on the issue of their current existence or non-existence. $\mathrm{He}$ mentioned that their homeland was by Buir Lake, focusing on their past social disorder and villainous acts perpetrated against Chinggis Khan's Mongol ancestors. He discussed six tribes and some individual Tatars still existing, yet simultaneously spoke of the annihilation of the Tatars as a nation. Moreover, one detects a hint of moralizing in the author's lament that if the Tatars had but been unified rather than quarreling, none could have resisted them [53, p. 37-44]. One feels that "Tatars" represent the people of Mongolia before Chinggis Khan brought them order, purpose, and glory, while "Mongols" are the same people after unification. It seems Rashid al-Din was obligated to interweave incompatible narratives into a single congruous account, and the author knew that "Tatar" had merely been abandoned at some point by the Mongol royalty. This can be inferred by the way he continually bolstered the usage of the Mongol name, rambling about Chinggis Khan's lineage, in an ethnographic discussion of another nation, as well as his attempts to explain away the persistence of the Tatar name.

If, however, we accept that his description of the Tatars was a serious attempt to convey historical facts, then we can take it that in his view there was a previous time when the local neighboring tribe of the Mongols was so famous that its prestige and name was apparently voiced across the whole of Eurasia. Problems occur when we compare such claims to what we find in the enormous body of what are termed "unofficial sources" which suggest that Tatars in the first decades of the thirteenth century were completely unknown to many sedentary peoples who only then began to use the term. 


\section{The Unofficial Sources}

There are three points on which unofficial sources (those not composed as part of the imperial historiography) challenge the narrative of the official sources.

A. Sedentary societies often did not know who the conquerors were.

B. Tracing Tatar retrospectively back from Europe suggests refugees from Mongolia used the label.

C. Stratigraphy: Earlier sources tend to use Tatar rather than Mongol.

\section{A. Sedentary societies often did not know who Tatars or Mongols were}

The presence of the term Tatar in medieval sources, diffuse in both geographical and genre contexts, means we have two possible explanations. One can assume either it spread during the Chinggisid conquests in the 1200s (Rubruck's claim) or that the name spread before those events (Rashid al-Din's claim). The latter point is challenged by the fact that as Chinggis Khan's forces advanced, thirteenth-century authors anywhere west of Mongolia regularly expressed bewilderment as to who the unknown Tatars were and had only a general idea of where they originated $[29$, p. $69 ; 30$, p. 147$]$.

The Mongols or Tatars were completely unknown to the Russians when their army first appeared on Russian borders in 1222-1223. This is evident from the first mention of this people in Russian literature - that famous passage found in the Novgorod First Chronicle:

"The same year, for our sins, unknown tribes came, whom no one exactly knows, who they are, nor whence they came out, nor what their language is, nor of what race they are nor what their faith is; but they call them Tatars ["и зовуть их Татары"], and others say Taurmen, and others Pecheneg people, and others say they are those of whom Bishop Mefodi of Patmos bore witness, that they came out from the Etrian desert which is between East and North ... God alone knows who they are and whence they came out" [1, p. 264; 36, p. 64].

The Russian chronicler repeatedly emphasized that this people was completely unknown before the disaster of the Kalka unfolded, and he did not have any idea that they would return in fourteen years to subjugate Russia, so this must be a very early record. Later, during the Mongol invasion of Europe in 1241, the Hungarian king wrote an urgent letter to the pope noting that a "hitherto unknown people" had invaded his country, "nationes que se Tartaros appellant" - "peoples who call themselves Tartars" [27, p. 65]. Matthew Paris, the English chronicler, asked in exasperation around the same time: "Where have such a people, so numerous, been hidden until now?" [30, p. 138]. In 1241, Emperor Frederick II wrote, "a barbarous race... (from what place or origin I know not) called Tartars has lately emerged from the regions of the south, where it had long lain hid, burnt up by the sun of the torrid zone" [24, v.1, p. 341]. In the Islamic milieu, the scholar Ibn Abi'l-Hadid (1190-1258) noted that despite combing texts for clues, he had been unable to find any allusion at all to the Tatars [20, p. 20-21]. It is also noteworthy that al-Idrisi's extraordinarily informed geographical treatise describes no Tatar or Mongol people. Europe, Russia and the western Islamic world were largely ignorant of any ethnic group in northeast Asia (besides vaguely rumored nations of Gog and Magog) and they took up the Tatar label only during the conquests. 


\section{B. Tracing the Tatar Name back from Europe}

It has already been clarified that the Tatar/Tartar name first reached Europe and its authors from outside informants along more than one chain of transmission. Before it reached Europe, we can continue to make further inferences that trace it further to a point of origin. We can identify the exact point when the name "Tatar" must have reached the Russian people and that would be in 1222, following the defeat of the Kipchaks by the forces of Jebe and Sübe'etei. Many Kipchaks had fled to the Russians to conference with them about making an alliance. Both the Galician-Volhynian and Novgorod Chronicle tell a very similar story of the defeated Kipchak survivors meeting with the Russian princes, offering gifts, and explaining that Russia would be next for destruction if the Tatars were not stopped by a coalition. This ultimately inspired the Russians to go to war which ended in defeat at the Kalka River [36, p. 64-65; 42, p. 28-29]. In the exchange of information, the name of the enemy people must have been provided by the Kipchak. The Kipchak chieftain, Kuthen, later fled to Hungary as a refugee in 1239, first sending emissaries to the Hungarian king to report the Tatar invasion of his land [10, p. 137]. Cumans and Hungarians referred to their mutual enemy as Tatars according to Alberic of Trois-Fontaine. In 1223, the Hungarians already had detailed information on the Battle of the Kalka, suggesting Kipchak informants [23, p. 110]. So, it is probable that the Kipchaks were calling the Mongols "Tatars" in the early 1220 s.

Tracing the term back from the Kipchak becomes much more speculative. It could be that they received it during the 1222 northward advance of Jebe and Sübe'etei from the Caucasus; Rashid al-Din records direct communication happening between the two groups, with the Mongol forces appealing to the Kipchak on the basis of shared heritage [53, p. 257]. Another possibility, more likely in my view, is that the Merkid refugees who fled Mongolia and found refuge with the Ölberi Kipchak already in 1210 or as late as 1218 [3, p. 9] must have described the people they had fled as "Tatars." Rashid al-Din recorded that after the defeat and death of the Merkid leader, Toqtoa Beki, his son Qodu fled to the Kipchak to 1208. He recorded that Qodu and his sons first passed through Uyghur territory and communicated with the Idiqut, getting in a conflict over slain messengers [53, p. 198-199]. The biography in the Yuan Shi of a Kipchak chieftain, Tuqtuq, records that after the Merkid prince took refuge with the Ölberi Kipchaks, Chinggis Khan's messengers showed up and communicated directly with the Kipchak, demanding they hand over the refugees [49, p. 3131]. If Chinggis Khan's people were really going by "Mongol," it is worth wondering why the Kipchak obviously shared the term "Tatar" even after they had direct communication with refugees from Mongolia and Chinggis Khan's messengers. Friar Julian found nobody able to read Ögedei's letter in Mongolian to Béla IV until he came across a local Kipchak who interpreted it, which suggests at least some Kipchaks understood Mongolian by the 1230 s [21, p. 178].

Pointing to a kernel of truth to Rashid al-Din's claim, it is possible that "Tatar" as the name of the Mongolic-speaking, animist people of Mongolia was already known and used among other mainly Turkic-speaking steppe peoples. Mahmud alKashgari's Compendium of Turkic Dialects (1077) offers a clue as to how the 
Turco-Mongol world was understood by Turkic peoples themselves a century before Chinggis Khan's rise. It laid out twenty large Turkish tribes extending west to east across Eurasia, starting with the well-attested Pechenegs and Kipchaks. At the northeast of this spectrum was the Tatar, with only the Kyrgyz farther east and closer to China. It indicated the Tatars had their own language, but they also knew Turkic [17, p. 82-83]. Presumably that language was Mongolic. Support for this identification comes from the portrayal of Tatars as polytheistic idolaters [17, p. 270]. It is not justified to refuse this identification owing to the author's designation of the Tatars as Turks when he clearly stated they speak another unintelligible language. Ibn al-Athir, Juzjani, and Rashid al-Din habitually called the Mongols a nation of Turks and recorded the Mongols appealing to Turkic groups on the basis of common ethnicity.

Refugees from Mongolia in the first decade of the thirteenth century must have had a huge role in the dissemination of the Tatar name to more distant societies. Küchlüg the Naiman prince fled as a refugee to the Qara Khitai by 1210. Juvaini noted that Küchlüg's Naimans had quickly dispersed throughout a vast territory after their flight from their homeland and he had to reassemble them after he was given permission to reside in the Qara Khitai state [13, p. 62-63]. These refugees were only hunted down and destroyed by Jebe in 1218 [11, p. 402-403]. As well, the Merkid refugees of Qodu were destroyed by Mongol forces in present-day Kazakhstan only around 1218 [5, p. 49]. In both these cases, tribes that had lived in Mongolia found homes amongst other distant peoples and had much time to share information about current affairs in Mongolia before their respective annihilations. An Arabic source, repeated by al-Dhahabi, noted that Mongol invasions in the 1220s saw eastern Anatolia and the whole adjacent region flooded with Turkic refugees fleeing from Georgia westward, and that the Mongols sent emissaries to the local potentates from their first appearance in the area [57, p. 115-123]. The Mongols used direct communication, interpreters, messengers etc. to an astounding degree which makes the lack of references to "Mongols" in the 1220s and 1230 s hard to understand.

There was evidently a good deal of movement of people and information along the network of interconnected Turkic peoples. The distances refugees travelled in a short time are astounding. Khwarazmian cavalrymen, whose base had been Inner Asia until their defeat by the Mongols in the 1220s and final collapse in 1231, found themselves invited into the service of the sultan of Egypt. They defeated Crusaders near Jerusalem in 1244 [45, p. 53-54]. I contend that groups of nomads from the Mongolian plateau, fleeing westward and southward, must have identified Tatars as the cause of their panicky flight. In this sense, there is also a kernel of truth to William of Rubruck's claim that the frequent refrain, "The Tartars are coming" [18, p. 123], caused the dissemination of the Tatar ethnonym. Refugees must have been consistently transmitting the name Tatar in the first several decades of Mongol conquests and that is how it so quickly began showing up in the literature of sedentary peoples as the name of Chinggis Khan's nation. If "Tatar" travelled through linked Turkic communities stretching across Eurasia in the first three decades of the thirteenth century, this raises questions. Did people from the Mongolian plateau not know the difference between a Tatar and a Mongol? How could people so steeped in the languages and ethno-political divisions of the region misidentify their enemies? Was there actually a misidentification? 


\section{Stratigraphy: Earlier sources use Tatar rather than Mongol}

Stratigraphy in archaeology relates to the tendency for lower layers of soil to contain older artifacts, and upper layers to contain newer ones. What if we were to imagine the entire corpus of primary source materials arranged in layers based on their dates of composition? I conjecture that the lower layers (before 1200) would show some regular examples of Tatar in sources, but Mongol would be close to non-existent. From 1206 to 1250, we would see a marked increase in examples of Tatar with some examples of Mongol. Around 1250, we would see an increased use of Mongol and appearances of Mongol-Tatar. From 1250-1370, we might see Mongol more often than Tatar.

Though certainly not the pan-Eurasian byword suggested by Rashid al-Din, the Tatar name is at least attested and had continuity in the centuries before 1206. It appears in the Orkhon inscriptions (700s), Uyghur inscriptions, and Tang records. There are scattered references in Persian geographic and ethnographic literature such as the Hudud al-Alam (980s) and Gardizi's eleventh-century study of the various tribes of the Turks [35, p. 120]. Tatars are named in al-Kashgari's Compendium of Turkic Dialects. By contrast, historians can find only a few, oftenspeculative cases of "Mongol" being recorded before the thirteenth century [51, p. $3-9]^{5}$.

In materials dating from the mid-1240s or prior, we often see bizarre statements if we hold to the view that Chinggis Khan, his descendants, and people already called themselves Mongols at that time:

- "If you want to do battle, you shall know this: in the great nation of the Qa'an, we Tatars (達達) have gathered all the nations surrounding us in the four directions." - Ögedei Khan's letter to the king of Korea dated to 1231, recorded in the Koryo-sa [33, p. 228-229].

- "But [the Tatars] leave behind other farmers to cultivate the fields, and they divide the [female] relatives of everyone [...] among the men left behind to cultivate the fields, assigning to them ten or more. And they command them henceforth to be called Tartars." - Friar Julian's letter describing the conquest of the Volga region, 1237-1238 [21, p. 176-177].

\footnotetext{
${ }^{5}$ The etymology and origins of Mongol are unknown. Based on its earliest documented appearances in the Jiu Tang Shu (舊唐書) c. 940, and Xin Tang Shu (新唐書) in 1060 as the name of a small branch of the larger Shiwei (室韋) tribes in the Tang period, I wonder if it was originally related to the Mohe people (靺鞨) of the Balhae (渤海) Kingdom. In Korean, which preserves older pronunciations, the group is called Malgal (말갈). The eleventh-century Xin Wudai Shi describes ethnic and political connections between the Tatar (韃靼) and Mohe in Balhae's time [60, section 2, p. 3]. Could disorder and displacement in Balhae have led to the westward move of a Mohe grouping, perhaps aristocracy, who attained control over a branch of the Shiwei and lent it their name in some form? We might think of the "Khitanopa" ("китанопа") noted in the Rus' Chronicles in 1103 as a tribal grouping of Cuman-Kipchak union. In Peter Golden's view, they had likely migrated from the Khitan State before the Liao's fall [25, p. 268-269]. It is not useful to imagine tribal nomenclature had to conform to watertight, unchanging Mongolic, Turkic, and Tungusic linguistic groupings.
} 
- An Armenian gospel called the invaders in 1236 the Haratatar (Black Tatar) [52, p. 330].

- In 1245, Batu told Daniel of Galicia, who had come to pay homage, that he should drink kumis since he was "already one of them, a Tatar." - Galicia-Volhynia Chronicle [42, p. 58].

Besides the aforementioned Chinese records' use of Tatar rather than Mongol in the first half of the 1200 s, we see the same naming tendency in the writings of other societies. Ibn al-Athir lived roughly in the same timeframe as Chinggis Khan and provided a very early record on the Mongol Empire's initial expansion westward. He referred to the invaders as Tatars, viewing them as a variety of Turk in keeping with the notion described by al-Kashgari of a spectrum of Turk tribes across Eurasia. Though he even correctly identified that Chinggis Khan's given name was Temujin, and the location of his homeland, he never once mentioned the term "Mongol" [46, p. 204-205]. That a writer living in Damascus and Mosul was referring to Chinggis Khan's ethnic group as Tatars already in the early 1220 s suggests how rapidly this designation was adopted by sedentary society.

Muhammad al-Nasawi, writing before 1242, recorded the specific names of merchants working as go-betweens whose monikers reveal them to be from Bukhara, Otrar etc. Employed by Chinggis Khan, they were familiar with both societies as they moved between the territories of Chinggis Khan and the Khwarazmian Shah in the period before war broke out in 1218. The author took part and had access to the accumulated direct correspondence between the two sides as Jalal alDin's secretary [28, p. 57, 120-121]! Yet he records that his masters fought desperately against "Tatars" rather than Mongols. If one wants to argue that this term "Tatar" was merely substituted into historical records in place of Mongol, or was not used in official correspondences, then one should explain why Eljigidei's messengers explained to Louis IX in 1248 that their homeland is Tatar, "which is why we are called Tatars" [56, p 129].

Rogerius, a prisoner of Batu's forces in 1241, never once mentioned "Mongol" in his work. Kirakos of Gandjak was likewise a prisoner, captured by the Mongols in Armenia in the 1230s. Despite the monk's familiarity with the Mongols and their language since he worked for them, he consistently called them Tatars in his history, only once referring to "Mughal Tatars" as Ögedei Khan's own people [12, p. 195]. However, it is not surprising since he wrote from perhaps the 1240 s to the 1260 s, when we start to see the general phenomenon of Mongol regularly appearing in the sources. Juzjani, a refugee in the Delhi Sultanate writing in about 1260, hated the Mongols - and yet he referred to them as Mughals, even if he described Ong Khan, "the Tattar," as chief of the Mughals before Chinggis [44, p. 935].

Juvaini, who was a high-up in the Mongol bureaucracy in Persia, writing a history in the 1250s, occasionally called his Mongol overlords the "Tatars." In his description of the birth of the empire, he designated Chinggis Khan's homeland as the Land of the Tatars who lived in disorder before he rose as their king. Moreover, Juvaini always used Tatar to refer to the Mongols in general and never to refer to the rival tribe in eastern Mongolia; the following statement suggests Mongol was broadly synonymous with Tatar: "And since the Tartar [Tatār] peoples had no script of their own, he [Chinggis Khan] gave the order that Mongol children should learn writing from the Uyghur" [13, p. 20-21, 25]. 
As a general overview, by the 1240 s, it is clear from the Mendicant Latin emissaries that at least Mongolian royalty were baulking at being called Tatars. By the $1250 \mathrm{~s}-60 \mathrm{~s}$, the Toluid revolution and historiography project was under way. In the resulting official texts, the ethnic group of the empire's founder and his ruling descendants was unequivocally Mongol.

Two final considerations related to early Chinese sources in the proverbial stratigraphic layers are of special interest for my argument. First, Li Xinchuan's Jianyan yilai chaoye zaji, completed in 1216 mentions that Tatars and Mongols were two distinct tribes with distant homelands, but their ethnonyms had been mixed together for unknown reasons and Jin frontier officials were now referring to “Mongol-Tatars" (蒙鞋) [34, p. 848-849]. At a glance, this passage seems to buoy the traditional view that Mongols became mislabeled as Tatars. On the contrary, Li Xinchuan was expressing mystification that the ruler of the Tatars, "Chinggis" (成吉思), and his Tatar people had adopted the label of Mongol, presently referring to themselves as the Great Mongol State (至是鞋靼乃自號大蒙古國), when in fact the Mongol tribe originally dwelt northeast of the Jin Empire but had made inroads against it and had children with Khitan and Han Chinese in the 1100s. Ethnically, Chinggis Khan was a Black Tatar according to Li Xinchuan [39, p. 6] and the autonym of the people invading Jin China under his direction in the 1210s was clearly “Tatar” (鞋靼) [34, p. 850-851]. Li Xinchuan's testimony agrees with the Song emissaries - Mongol was a dynastic-state label adopted by the Tatars.

Secondly, the Secret History and related sources document an early event in Chinggis Khan's rise when he joined with Ong Khan of the Kereyit and a Jin expeditionary force to defeat the Tatar tribes at the Ulz River in northeastern Mongolia. This resulted in Chinggis Khan receiving a military rank and Ong Khan receiving his royal title, wang, from the Jin commander (19, p. 56-58; 41, p. 191-192). Here we have the rare opportunity to compare the official account of a pre-unification event in Mongolia with unofficial sources. The Serven Khaalga inscription, engraved in Chinese and Jurchen, commemorates the engagement and firmly dates it to 1196. In it, the defeated tribal group is not recorded as Tatar but rather as the “Northern Shubo" (北术孛) [48, p. 33]. Shubo or Shubugu ((术不姑)), most commonly rendered in Chinese sources as Zubu (阻卜), describes people on the Liao's northwest frontier, i.e. Mongolia [59, p. 95], and is considered by modern Chinese scholars to be a Khitan word to designate Tatars. The Zubu were classified as a tribe rather than state in the Liao era [59, p. 319]. The term is likely related to Sogpo which Tibetans used to refer to the Mongols in general. Since Tatar, a term appearing in Chinese texts already in 842, was absent from the official histories of the preceding Liao and Jin dynasties, the Liao Shi and Jin Shi, compiled under Yuan auspices, Wang Guowei suggested "Zubu" was employed as a substitute for Tatar [59, p. 101-102]. Yet, the 1196 inscription must cause us to rethink that thesis. Since Ong Khan's grandfather was described as a Zubu in Jin sources, it would appear to apply as a general term for Mongol peoples. Indeed, there is an account of the poor people of the Zubu being resettled by the government in 1098 in the Liao Shi which evokes the byword of past misery and chaos before Chinggis Khan remembered by the Mongols themselves [59, p. 395]. Since it could be an exonym, Zubu's usage in the Jin era does not disprove northeast Mongolian tribes called 
themselves Tatar, but this source does not help corroborate the ethnographic picture in the Secret History.

The Mengda Beilu also provides a loose outside view of these events, noting that the Jin Zhangzong Emperor (r. 1190-1208) ordered northward punitive expeditions against the "Jiu" (幻) who were rising in rebellion, and they fled and surrendered to the Tatar (i.e. Mongols) [39, p. 60]. It is interesting to note that this account suggests the war was against Jiu - frontier military garrisons employed by the Jin rather than a distinct ethnic group. This could relate to Rashid al-Din's insistence that the pre-unification Tatar nation's dwelling places were "near the territories of Cathay" (Jin territory) and that they had long paid tribute to the Jin [53, p. 37]. By the fourteenth century, maybe "Tatar" was the label unfavorably singularly applied to those Mongolic-speaking tribes who lived closest to the former Jin and had made sneaky deals with them in the past - border tribes whose delineations were related to political allegiances.

\section{Conclusions and Explanations}

Explanations in primary sources do not clear up the confusion surrounding "Mongol" and "Tatar." There is no way to tidily reconcile claims regarding what they respectively meant and why so many people were mistakenly calling Mongols by the name of former enemies. Thus, I share a viewpoint that the Mongols selfidentified as Tatars during the early decades of the Mongol Empire's expansion. Paul Ratchnevsky thought that Mongols still called themselves Tatars in Chinggis Khan's time [43, p. 7]. Atwood also has implicitly accepted this idea, demonstrating a pattern with nomadic and Altaic empires having two ethnonyms, a subordinate and ruling one, associated with their founders. Often, the former name comes to be rejected. Mongols rejected Tatar, just as the Uyghur abandoned Oghuz and the Manchus later rejected the old Jurchen ethnonym after taking power. As a trend, the original broader ethnonym, used by foreigners, sometimes evolved to denote "slave" [8, p. 36-38]. Since it seems implausible that tribal groups prearranged for a new ethnonym should they ever win an empire, this "rebranding" phenomenon is likely an organic one.

Accepting the primacy of the official sources on the naming issue raises more problems than it resolves, even while they undoubtedly describe individuals and groups which existed, real conversations, and battles that were fought. I am not trying to deny that in 1202, Chinggis Khan massacred a number of tribes - their leaders' names are likely recorded accurately. Nevertheless, I contend that the testimony of Song envoys to the Mongol court in the 1220s and 1230s is the most reliable evidence for how Tatar and Mongol were used by Mongolian steppe people themselves at that time. Thus, Mongol initially was a political identity that evolved into an ethnic identity, first being adopted and promoted by the dynasty and aristocracy. Tribal groups could spontaneously abandon ethnic identities and manufacture or adopt others quite easily over the course of several generations. Ibn Khaldun, the fourteenth-century philosopher, noted this as a universal sociological phenomenon:

"It is clear that a person of a certain descent may become attached to people of another descent [...] Such a person comes to be known as having the same descent as those (to whom he has attached himself) and is counted one of them [...] When 
the things which result from (common) descent are there, it is as if (common descent) itself were there [...] In the course of time, the original descent is almost forgotten. Those who knew about it have passed away, and it is no longer known to most people. Family lines in this manner continually changed from one tribal group to another [...] This happened both in pre-Islamic and in Islamic times, and between both Arabs and non-Arabs" [47, p. 267-268].

If the genealogies of aristocracy and founders of steppe empires could not be kept consistent, one can imagine the rank and file's backgrounds could be remolded with even greater ease. For perspective, consider the Khitan Liao who ruled Mongolia and northern China (907-1125). The Liao's tribal nucleus was comprised of groups first held together on the basis of the need for joint military action [59, p. 46]. Gradually, however, they adopted a shared myth of origin with a common ancestor. With the establishment of their empire, intermarriage between tribes remained very fluid. The Liao Shi details the number of Khitan tribes fluctuating rather wildly from six to twenty in the three centuries before the establishment of the Liao Dynasty. On the whims of rulers, tribes were reorganized, disbanded, created, or resettled. As Wittfogel and Feng observed, "Pastoral nomadism favored neither a stable clan order nor a fixed place of residence" [59, p. 46-48]. We can see the same patterns on a grander scale in the expansive and culturally diffuse Mongol state which followed it - particularly with the myth of common ancestry from a blue wolf and fallow deer as is reflected in the Secret History.

Why did the Mongol rulers or people feel the need to abolish the Tatar ethnonym and replace it with Mongol? Here I can only offer speculative conclusions. Friar Julian's report and the Heida Shilue suggest strongly that the Tatar name was still used in the mid-1230s, and the Mendicant emissaries in the mid1240s stated unequivocally that the people called themselves Mongols, so it appears that the project of ethno-dynastic "rebranding" was initiated between those points. One motivator could be the fall of the Jin Dynasty (1234) triggering a stronger sense among the Mongols of their legitimacy, mandate of world-rulership, and need for inclusiveness between the tribes assembled under the Mongol Empire's banner.

A particularly intriguing impetus could have been ongoing problems of rebellion and social unrest among the eastern Usu Irgen "Water Tatar" people mentioned in the 1230s Heida Shilue [39, p. 209]. Carpini and C. de Bridia likewise referred to "Zumoal" (Water Mongols) who "called themselves Tatars after a great, rushing river called Tatar," lived in eastern Mongolia, and were the first to be subjugated by Chinggis Khan [40, p. 56]. Juvaini mentions that Ögedei sent armies to suppress the "Su-Moghol" around 1234 [13, p. 196]. In 1261, the Yuan Shi records that Khubilai Khan appointed a Pacification Commissioner (宣掹使) over the Water Tatar (水達達) and Jurchens in the east [49, p. 73]. All of this hints that eastern Mongolia's people were sometimes rebellious and unwilling subjects, which might have formed the context in which imperial historiography of the 1250s and $1260 \mathrm{~s}$ attached the defunct Tatar ethnonym uniquely to these unruly people and wrote their annihilation as a distinct group into history.

Apparently, Ögedei banned the ethnonym "Qashi” and changed the Qashin nation's name to Tangut after the death of his fifth son, Qashi [53, p. 66, 302]. Besides taboos, a name-change could be driven by insecurities. Was the Tatar name 
being used contemptuously by subjects and enemies? Were rivalries between Chinggis Khan's grandsons establishing new "in" and "out" groups? The legitimization of dynasties often required tampering with records to create myths and new collective identities. Some claims on the lineage of Chinggis Khan might be no more trustworthy than Ulugh Beg's claim, inscribed on his grandfather Timur's tombstone in 1425, that he miraculously descended from Ali, the son-in-law of Muhammad [37, p. 37]. Grandchildren of a dynasty-founder needed to prove that the dynasty did not start because their grandfather was a particularly successful usurper or bandit leader. If mid-thirteenth century patrons of court historians desired to be called Mongols, and abolish Tatar, this could merely be written retrospectively into the narrative - especially since old-timers who took part in the events had passed away. Motivated by expediency rather than facts, the author could have Chinggis Khan annihilate all "Tatars" completely, and then there would be no reason to mention their name again.

As a caveat, some scholars have suggested that maybe Muqali and other Mongols just called themselves Tatars out of politeness to Chinese visitors [39, p. 4]. But eventually the Mongols did protest too much about the use of Tatar for me to see this issue as a coincidental, continent-wide misnaming. With the overthrow of the Mongol Yuan Dynasty in 1368, and the rise of the Chinese Ming Dynasty, the term "Tatar" in reference to the Mongols returned to Chinese writings. Regarding Chinggis Khan and his people, a late Ming encyclopedia, the Sancai Tuhui, records: "He was called the chief of the Great Mongols. He usurped the title of Emperor. For generations [the Mongols] lived [at a distance of] 6000 li north-east of the Sandy Desert. Later they lived on the north side of the mountains [between China and Mongolia]. They called themselves Ta-ta [Tatar]" [16, p. xxix].

If we accept this statement regarding self-identification within the militarytribal confederation that arose in the steppe, then Mongol ethnic identity was at least partly a creation of Chinggis Khan and his immediate successors. Carpini's "Mongols whom we call Tartars" had once been Tatars - whom we now call Mongols. A Mongolian linguistic and cultural identity existed before Chinggis Khan but the specifically "Mongol" national identity and predominant ethnonym must be products of Chinggis Khan's empire-building project. If so, this only confirms what has long been said: Chinggis Khan is the father of the Mongolian people. Regarding the Volga Tatar people of today, it appears they took on the endonym of their Mongol conquerors when they overran the Dasht-i-Kipchak. It was preserved as the prevailing ethnonym in the subsequent synthesis of the Mongols and their more numerous Turkic subjects who ultimately subsumed their conquerors culturally and linguistically as al-Umari noted by the fourteenth century [32, p. 141]. I argue that the name "Tatar" was adopted by the Turkic peoples in the region as a sign of having joined the Tatar conquerors - a practice which Friar Julian reported in the 1230s as the conquest unfolded. The name stands as a testament to the survivability and adaptability of both peoples and ethnonyms. It became, as Sh. Marjani stated, their "proud Tatar name." 


\section{REFERENCES}

1. Novgorodskaya Pervaya letopis' starshego i mladshego izvodov [Novgorod First Chronicle according to the Oldest and Younger Transcripts]. Nasonov A.N. (red.). Moscow-Leningrad: Akademiya Nauk SSSR Publ., 1950. 561 p. (In Russian)

2. Abramowski W. Die chinesischen Annalen von Ögödei and Güyük: Übersetzung des 2. Kapitels des Yüan-shih. Zentralasiatische Studien. 1976, no. 10, pp. 117-167. (In German)

3. Allsen T.T. Prelude to the Western Campaigns: Mongol Military Operations in the Volga-Ural Region, 1217-1237. Archivum Eurasiae Medii Aevi. Wiesbaden, Otto Harrassowitz Verlag, 1983, no. 3, pp. 5-24.

4. Atwood C. Commentary of Shengwu qinzheng lu 聖武親征錄. Commentary Project of the Center for Central Eurasia Civilization Archive, pp. 1-22.

5. Atwood C. Jochi and the Early Western Campaigns. How Mongolia Matters: War, Law, Society. Morris Rossabi, (ed.). Leiden, Brill, 2017, pp. 35-56.

6. Atwood C. Six Pre-Chinggisid Genealogies in the Mongol Empire. Archivum Eurasiae Medii Aevi. Wiesbaden, Otto Harrassowitz Verlag, 2012, no. 19, pp. 5-58.

7. Atwood C. The Date of the 'Secret History of the Mongols' Reconsidered. Journal of Song-Yuan Studies. 2007, no. 37, pp. 1-48.

8. Atwood C. The Qai, the Khongai, and the Names of the Xiongnu. International Journal of Eurasian Studies. 2015, no. 2, pp. 35-64.

9. Bade D. Khubilai Khan and the Beautiful Princess of Tumapel. Ulaanbaatar, A. Chuluunbat, 2002. 244 p.

10. Bak J., Rady M. (trans.). Master Roger's Epistle to the Sorrowful Lament upon the Destruction of the Kingdom of Hungary by the Tatars. Budapest, Central European University Press, 2010. 326 p.

11. Barthold W. Turkestan down to the Mongol Invasion. Minorsky T., Bosworth C.E. (trans.). London, Luzac, 1968. 596 p.

12. Bedrosian R (trans.). Kirakos Gandzakets'i. History of the Armenians. New York, Sources of the Armenian Tradition, 1986.

13. Boyle J. (trans.). Ala al-Din Ata Malik Juvaini, The History of the World Conqueror. Cambridge, Cambridge University Press, 1958. 763 p.

14. Brundage J. (trans.). The Chronicle of Henry of Livonia. Madison, University of Wisconsin Press, 1961. xliii +288 p.

15. Chambers J. The Devil's Horsemen. Edison, Castle Books, 2003. xii + 190 p.

16. Cleaves FW (trans.). The Secret History of the Mongols. Cambridge, Harvard Press, 1982. lxv $+277 \mathrm{p}$.

17. Dankoff R. (trans.). Mahmud al-Kashgari. Compendium of the Turkic Dialects. Cambridge, Harvard University, Dept. of Near Eastern Languages and Civilizations, 1982.

18. Dawson, Christopher (ed.). The Mission to Asia: Narratives and Letters of the Franciscan Missionaries in Mongolia and China in the Thirteenth and Fourteenth Centuries. London, Sheed and Ward, 1955.

19. de Rachewiltz I. (trans.). The Secret History of the Mongols: A Mongolian Epic Chronicle of the Thirteenth Century. Leiden, Brill, 2006. cxxvi $+1347 \mathrm{p}$.

20. Djebli M. Les invasions mongoles en orient vecues par un savant medieval arabe. Paris, Editions L'Harmattan, 1994. (In French)

21. Dörrie H. Drei Texte zur Geschichte der Ungarn und Mongolen. Göttingen, Vandenhoeck \& Ruprecht, 1956. 202 p. (In German, Latin)

22. Franke H. A Sung Embassy Diary of 1211-1212: The Shih-chin lu of Ch'eng Cho. Bulletin de l'Ecole française d'Extrême-Orient. 1981, no. 69, pp. 171-207.

23. Garufi C. (ed.). Ryccardi de Sancto Germano notarii Chronica. Rerum Italicarum Scriptores. Vol. VII/2. Bologna, Nicola Zanichelli, 1938. (In Latin) 
24. Giles J. Matthew Paris, English History: From the Year 1235 to 1273. 3 Vols. London, George Bell \& Sons, 1889.

25. Golden P. The Shaping of the Cuman-Qïpchaqs. Il Codice Cumanico e il suo mondo. Schmieder F., Schreiner P. (eds). Rome, 2005, pp. 247-277.

26. Hautala R. Crusaders, Missionaries and Eurasian Nomads in the $13^{\text {th }}-14^{\text {th }}$ Centuries: A Century of Interactions. Bucharest, Editura Academiei Romane, 2017. 477 p.

27. Hormayr J. Die goldene chronik von Hohenschwangau. Munich, G. Franz, 1842. (In German)

28. Houdas O. (trans.). Histoire $d u$ Sultan Djelal ed-din Mankobirti Prince $d u$ Kharezm par Mohammed en-Nesawi. Paris, Ernest Leroux, 1895. (In French)

29. Jackson P. The Mongols and the Islamic World. New Haven, Yale Press, 2017. $614 \mathrm{p}$.

30. Jackson P. The Mongols and the West. Harlow, Pearson, 2005. 414 p.

31. Jones S. (trans.). Kartlis Tskhovreba: A History of Georgia. Tbilisi, Artanuji Publishers, 2014. 443 p.

32. Lech K (trans.). Das mongolische Weltreich, Al-'Umari's Darstellung der mongolischen Reiche in seinem Werk Masālik al-abṣār fì mamālik al-amșār. Wiesbaden, Harrassowitz, 1968. 475 p. (In German)

33. Ledyard G. Two Mongol Documents from the Koryŏ sa. Journal of the American Oriental Society. 1963, no. 83, pp. 225-239.

34. Li Xinchuan 李心傳. Jianyan yilai chaoye zaji 建炎以來朝野雜記 [Notes on court and provinces since 1127]. Beijing, Zhong Hua Book Company, 2000. (In Chinese)

35. Martinez A. Gardizi's Two Chapters on the Turks. Archivum Eurasiae Medii Aevi. Wiesbaden, Otto Harrassowitz Verlag, 1982, no. 2, pp. 109-217.

36. Michell R., Forbes N. (trans.). The Chronicle of Novgorod 1016-1471. London, Camden Society, 1914. xliii $+237 \mathrm{p}$.

37. Moin A. The Millennial Sovereign: Sacred Kingship \& Sainthood in Islam. New York, Columbia University Press, 2012.

38. Morgan D. The Mongols. Malden: Blackwell Publishing, 2007. 272 p.

39. Olbricht P., Pinks E. (trans.). Meng-ta pei-lu und Hei-ta shih-lüeh: Chinesische Gesandtenberichte über die Frühen Mongolen 1221 und 1237. Wiesbaden. Harrassowitz, 1980. (In German)

40. Painter G. (trans.). The Tatar Relation. The Vinland Map and the Tartar Relation. Skelton R. et al. (ed.). New Haven: Yale University Press, 1995, pp. 20-106.

41. Pelliot P., Hambis L. (trans.). Histoire des Campagnes de Gengis Khan, Chengwou ts'in-tcheng lou. Leiden, Brill, 1951. xxvii + 485 p. (In French, Chinese)

42. Perfecky G. The Hypatian Codex, Part II: The Galician-Volynian Chronicle. Harvard Series in Ukrainian Studies 16:2. Munich, 1973. 159 p.

43. Ratchnevsky P. Genghis Khan: His Life and Legacy. Oxford, Oxford University Press, 1991. $328 \mathrm{p}$.

44. Raverty G. (trans.). Minhaj Siraj Juzjani, Tabakat-i-Nasiri: A General History of the Muhammadan Dynasties of Asia. London, 1881.

45. Richard J (ed.). Simon of Saint-Quentin. Histoire des Tartares. Paris, Librairie orientaliste Paul Geuthner, 1965. (In French, Latin)

46. Richards D.S. (trans.). Ibn al-Athir, The Chronicle of Ibn al-Athir for the Crusading Period from al-Kamil fi'l-ta'rikh. Part 3: The Years 589-629/1193-1231: The Ayyubids after Saladin and the Mongol Menace. Aldershot, Ashgate, 2008. viii + 331 p.

47. Rosenthal F (trans.). Ibn Khaldun. The Muqaddimah. Vol. 1. London, Routledge, 1958. $481 \mathrm{p}$.

48. Shiraishi, N. 斡里札河の戦いにおける金軍の経路 [Route of Jin army in the Battle of the River Ulz]. Inner Asian Studies. 2016, no. 31, pp. 27-48. (In Japanese) 
49. Song Lian 宋濂. Yuan Shi 元史 [History of Yuan Dynasty]. Beijing, Zhong Hua Book Company, 1976. (In Chinese)

50. Szentpétery I. Scriptores rerum hungaricarum tempore ducum regumque stirpis arpadianae gestarum. 2 Vols. Budapestini, Academia litter. hungarica atque Societate histor. hungarica in parten impensarum venietibus, typographiae Reg. universitatis litter. hung. sumptibus, 1937-1938. Vol. 2. 681 p. (In Latin)

51. Tamura J. The legend of the origin of the Mongols and problems concerning their migration. Acta Asiatica. 1973, no. 24, pp. 1-19.

52. Tatár M. The First Tatars in Europe. Altaica Budapestinensia MMII. Budapest, MTA, 2003, pp. 328-352.

53. Thackston W. (trans.). Rashiduddin Fazlullah's Jami'u'tawarikh: Compendium of Chronicles. $2^{\text {nd }}$ edition. Cambridge, Harvard University Department of Near Eastern Languages and Civilizations, 1999. $811 \mathrm{p}$.

54. Vasaru M. Bjarmaland. Oulu, University of Oulu, 2016. 486 p.

55. Vásáry I. Cumans and Tatars. Cambridge, Cambridge University Press, 2005. 230 p.

56. Viard J (ed.). Les Grandes Chroniques de France. Tome 7. Paris, Librairie Ancienne, 1932. 296 p. (In French)

57. Von Somogyi J. Ein arabischer Bericht über die Tataren im Ta'rīh al-Islām von adDahabī. Der Islam. 1937, no. 24(2), pp. 105-130. (In German)

58. Weatherford J. Genghis Khan and the Making of the Modern World. New York, Crown Publishers, 2004. 293 p.

59. Wittfogel K., Feng C. History of Chinese Society Liao (907-1125). Transactions of the American Philosophical Society. 1946, vol. 36, 752 p.

60. Yanai Wataru 箭內互. Wulianghe ji dada kao 元良哈及鞋靼考 [Uriyangqat and Tatar Studies]. Taiyuan, Shanxi People's Press, 2015. (In Chinese)

About the author: Stephen Pow - M.A. (History), PhD Candidate, Department of Medieval Studies, Central European University (Nádor utca 9, 1051 Budapest, Hungary); ORCID: http://orcid.org/0000-0001-8804-0397. E-mail: Pow_Stephen@phd.ceu.edu

\title{
«NATIONES QUE SE TARTAROS APPELLANT»: ИССЛЕДОВАНИЕ ИСТОРИЧЕСКОЙ ПРОБЛЕМЫ ИСПОЛЬЗОВАНИЯ ЭТНОНИМОВ ТАТАР И МОНГОЛОВ В СРЕДНЕВЕКОВЫХ ИСТОЧНИКАХ
}

\author{
Стивен Поу \\ Центрально-Европейский университет \\ Будапешт, Венгрия \\ Pow_Stephen@phd.ceu.edu
}

Цель исследования: в статье предпринята попытка объяснить, почему монголы так часто именуются татарами в первоисточниках XIII века, и предложить новую интерпретацию того, как использование этих этнонимов развивалось в ходе экспансии и распада Монгольской империи. 
Материаль исследования: в статье использованы первоисточники, написанные монгольскими, латинскими, русскими, арабскими, китайскими и корейскими авторами. Русские Новгородская и Галицко-Волынская летописи, Тайная история монголов, Рашид ад-Дин, Юань Ши и Мэнда Бейлу оказались наиболее важными для формулировании аргументации. В статье были также использованы публикации ведущих исследователей монгольской истории.

Результаты и новизна исследования: основной вывод заключается в том, что различные объяснения, найденные в первоисточниках, составленных при монгольских правительствах, в отношении того, как эти имена использовались в доимперский период, как и в отношении феномена двойного именования, кажутся неправдоподобными при сравнении с более широким кругом первоисточников, авторы которых не находились под влиянием монгольской имперской идеологии. Кроме того, эти объяснения не могут быть объединены в какую-либо работоспособную модель, отображающую появление двойного именования в XIII веке, поскольку они противоречат друг другу по таким фундаментальным вопросам, как, например, существовали ли татары или же они были вымершей нацией. Таким образом, более правдоподобным представляется то, что монголы использовали имя «татар» для самоидентификации в первые три или четыре десятилетия экспансии Монгольской империи. Постепенная замена «татар» на «монголов» была закреплена развитием имперской историографии в 50-х и 60-х годах XIII века. Это может объяснить странную дихотомию в первоисточниках относительно этих этнонимов. Новизна заключается в сопоставлении китайских и европейских источников и в попытке обобщить их утверждения - подход, который выделяет потенциальные направления исследований для экспертов исламских, русских и китайских источников.

Ключевье слова: татары, монголы, Монгольская империя, Золотая Орда, русские летописи, этнонимы, ранняя Монгольская империя, средневековый этногенез, Чингиз-хан

Для цитирования: Pow S. "Nationes que se Tartaros appellant": An Exploration of the Historical Problem of the Usage of the Ethnonyms Tatar and Mongol in Medieval Sources // Золотоордынское обозрение. 2019. Т. 7, №3. С. 545-567. DOI: $10.22378 / 2313-6197.2019-7-3.545-567$

Сведения об авторе: Стивен Поу - докторант Отдела средневековых исследований Центрально-Европейского университета (Nádor utca 9, 1051 Budapest, Hungary); ORCID: http://orcid.org/0000-0001-8804-0397.E-mail: Pow_Stephen@phd.ceu.edu 